\title{
Characterization of $\mathrm{Sm}$ and $\mathrm{Nd}$ Co-Doped Ceria-Based Electrolyte Materials
}

\author{
A. ArABACI ${ }^{a, *}, \ddot{O} \cdot \operatorname{SERIN}^{a}, \mathrm{~V} \cdot \mathrm{SARIBOĞ}^{b}$ AND M.F. ÖKSÜZÖMER ${ }^{b}$ \\ ${ }^{a}$ Istanbul University, Faculty of Engineering, Department of Metallurgical Engineering, \\ Avcilar, 34320 Istanbul, Turkey \\ ${ }^{b}$ Istanbul University, Faculty of Engineering, Department of Chemical Engineering, Avcilar, 34320 Istanbul, Turkey
}

\begin{abstract}
Ceria doped with trivalent cations, such as rare earth elements, is considered to be one of the most promising electrolyte materials for intermediate-temperature solid oxide fuel cells, which are an alternative to the commercially used ytrium-stabilized zirconia (YSZ). The aim of this work research is to synthesize Sm and Nd co-doped ceria materials using the Pechini method as solid electrolyte for intermediate temperature solid oxide fuel cell. $\mathrm{Ce}_{0.75} \mathrm{Sm}_{0.20} \mathrm{Nd}_{0.05} \mathrm{O}_{1.875}, \mathrm{Ce}_{0.65} \mathrm{Sm}_{0.20} \mathrm{Nd}_{0.15} \mathrm{O}_{1.825}$, and $\mathrm{Ce}_{0.60} \mathrm{Sm}_{0.20} \mathrm{Nd}_{0.20} \mathrm{O}_{1.80}$ have been chosen as target of this study. Microstructural and physical properties of the samples were characterized with X-ray diffraction, scanning electron microscopy, thermogravimetric analysis methods. The results of the thermogravimetry/differential thermal analysis and X-ray diffraction indicated that a single-phase fluorite structure formed at the relatively low calcination temperature of $600^{\circ} \mathrm{C}$ for $3 \mathrm{~h}$. The two-probe ac impedance spectroscopy was used to study the total ionic conductivity of doped and co-doped ceria ceramics at $800^{\circ} \mathrm{C}$. The $\mathrm{Ce}_{0.60} \mathrm{Sm}_{0.20} \mathrm{Nd}_{0.20} \mathrm{O}_{1.80}$ sample showed maximum ionic conductivity.
\end{abstract}

DOI: 10.12693/APhysPolA.129.524

PACS/topics: 88.30.pn

\section{Introduction}

Solid oxide fuel cells (SOFCs) have the potential as an alternative energy system in the future. Recently SOFCs have been attracting more attention due to high efficiency and clean energy. Electrolyte materials used for SOFCs are usually the main components determining the performance of the fuel cell. Yttria-stabilized zirconia (YSZ) is a standard electrolyte for conventional SOFC systems. To obtain the required level of ionic conductivity of YSZ, the operation temperatures are usually as high as $1000^{\circ} \mathrm{C}$. However, at such high operating temperatures, there are some problems such as thermal mismatch between cell components, chemical instability, etc. $[1,2]$. It is thus necessary to reduce the operating temperature of SOFCs. It is known that the replacement of YSZ electrolyte by the doped ceria that has high oxideionic conductivity at low temperature, is one of the most promising methods for lowering the operating temperature [3]. Especially, the use of rare earth elements such as $\mathrm{Nd}$, Sm and Gd as dopants for ceria improved the ionic conductivity of ceria [4-6]. To further improve conductivity of ceria based solid electrolyte materials, co-doped or double doped strategy have been used in many studies and most of them gave positive results [7-12].

$$
\text { In this work, } \mathrm{Ce}_{0.8} \mathrm{Sm}_{0.2} \mathrm{O}_{1.9} \quad \text { (SDC), }
$$
$\mathrm{Ce}_{0.75} \mathrm{Sm}_{0.2} \mathrm{Nd}_{0.05} \mathrm{O}_{1.875} \quad \mathrm{Ce}_{0.65} \mathrm{Sm}_{0.2} \mathrm{Nd}_{0.15} \mathrm{O}_{1.825}$ $\mathrm{Ce}_{0.6} \mathrm{Sm}_{0.2} \mathrm{Nd}_{0.2} \mathrm{O}_{1.8}$ samples were synthesized by simple Pechini method. The effect of the co-doping element on

*corresponding author; e-mail: aliye@istanbul.edu.tr structural properties and ionic conductivity was compared to singly-doped ceria (denoted as samarium-doped ceria for singular doping). The aim was to develop new ceria-based electrolyte materials to further improve the ionic conductivity. Microstructural and physical properties of the samples were characterized with X-ray diffraction (XRD), scanning electron microscopy (SEM), the Fourier transform infrared spectroscopy (FTIR), thermogravimetry (TG) analysis methods. Furthermore, the co-dopant effects on the ionic conductivity of the ceria based electrolytes were investigated.

\section{Materials and method}

Cerium nitrate $\left[\mathrm{Ce}\left(\mathrm{NO}_{3}\right)_{3} \cdot 6 \mathrm{H}_{2} \mathrm{O}\right.$, purity $99.999 \%$, Sigma Aldrich], samarium nitrate $\left[\mathrm{Sm}\left(\mathrm{NO}_{3}\right)_{3} \cdot 6 \mathrm{H}_{2} \mathrm{O}\right.$, purity $99.999 \%$, Sigma Aldrich], and neodymium nitrate $\left[\mathrm{Nd}\left(\mathrm{NO}_{3}\right)_{3} \cdot 6 \mathrm{H}_{2} \mathrm{O}\right.$, purity $99.999 \%$, Sigma Aldrich] were used as the starting materials. In order to prepare $\mathrm{Ce}_{0.8} \mathrm{Sm}_{0.2} \mathrm{O}_{1.9}, \mathrm{Ce}_{0.75} \mathrm{Sm}_{0.2} \mathrm{Nd}_{0.05} \mathrm{O}_{1.875}$, $\mathrm{Ce}_{0.65} \mathrm{Sm}_{0.2} \mathrm{Nd}_{0.15} \mathrm{O}_{1.825}, \quad \mathrm{Ce}_{0.6} \mathrm{Sm}_{0.2} \mathrm{Nd}_{0.2} \mathrm{O}_{1.8} \quad$ electrolyte samples, the nitrates were weighed and dissolved in the de-ionized water with the desired concentrations. Citric acid (anhydrous citric acid, Boehringer Ingelheim) was dissolved in de-ionized water and then was added with ethylene glycol (R.P. Normopur) to the cation solution. The molar ratio of total oxide (TO): citric acid (CA) and ethylene glycol:citric acid was selected as $2: 1,4: 1$, respectively. The obtained purple solutions were heated and stirred on a hot plate at $85^{\circ} \mathrm{C}$. With the evaporation of water, the solution was gradually transformed into a brown viscous gel. The gel was placed in an oven at $110^{\circ} \mathrm{C}$ for $24 \mathrm{~h}$ until it changed into a dark brown loose foam. Afterwards, the foam was 
placed in a furnace for further heating until autoignition of the foam took place and light green powders were produced. The powders were collected and calcined at $600{ }^{\circ} \mathrm{C}$ for $3 \mathrm{~h}$ to remove the carbon residue. The calcined powders were uniaxially pressed at a compaction pressure of $200 \mathrm{MPa}$ into $10 \mathrm{~mm}$ diameter pellets and sintering was performed at $1400^{\circ} \mathrm{C}$ for $6 \mathrm{~h}$.

Thermochemical properties of the dried loose foam were investigated by thermogravimetry/differential thermal analysis (DTA) (SII Exstar 6000 TG/DTA 6300) in the temperature range of $25-700{ }^{\circ} \mathrm{C}$ at a heating rate of $5^{\circ} \mathrm{C} / \mathrm{min}$ in air.

The X-ray spectra of Sm and Nd co-doped ceria particles were obtained over the $2 \theta$ range of $10-90^{\circ}$ by using Rigaku D/max-2200 ultima X-ray diffractometer with $\mathrm{Cu} K_{\alpha}$ radiation $(1.5406 \AA)$. The FT-IR spectra were recorded with a Perkin Elmer Spectrrum 100 instrument. FEIQUANTA FEG 450 scanning electron microscope was used to study the morphology and microstructure of the sintered samples. The elemental distribution of the sintered samples was also investigated by the energy dispersive X-ray spectroscopy (EDS), and the mapping images were obtained by scanning 32 frames. Impedance measurements (electrochemical impedance spectroscopy (EIS)) were taken by using SOLARTRON $1260 \mathrm{FRA}$ and 1296 interface at $800^{\circ} \mathrm{C}$ in air atmosphere.

\section{Results and discussion \\ 3.1. Thermal analysis}

The conversion of the so-prepared amorphous precursors into crystalline samarium-doped ceria was achieved by heating the dried solids at a heating rate of $5^{\circ} \mathrm{C} \mathrm{min}-1$ to $600^{\circ} \mathrm{C}$ and keeping them at this temperature for $3 \mathrm{~h}$. Figure 1 shows the simultaneous TGA/DTA curves of the dried $\mathrm{Ce}_{0.75} \mathrm{Sm}_{0.20} \mathrm{Nd}_{0.05} \mathrm{O}_{1.875}$ foam. The TG curve displays a minor weight-loss of $4.15 \%$ between 27 and $170^{\circ} \mathrm{C}$ which may be attributed to the water loss associated with foam. A strong exothermic peak in DTA curve along with a maximum weight loss of $55.2 \%$ that occurred at approximately $220^{\circ} \mathrm{C}$, may be due to the combustion of organic residues and the gradual crystallization of $\mathrm{Ce}_{0.75} \mathrm{Sm}_{0.20} \mathrm{Nd}_{0.05} \mathrm{O}_{1.875}$. The foam was observed to produce a self-sustained flame when it was kept in an oven at $220^{\circ} \mathrm{C}$. It is evident that this is the temperature for a vigorous combustion reaction of $\mathrm{Sm}-\mathrm{Nd}$-doped ceria-containing nitrate oxidant system.

No remarkable change can be seen at above in the TGA/DTA curves. This proves that $\mathrm{Ce}_{0.75} \mathrm{Sm}_{0.20} \mathrm{Nd}_{0.05} \mathrm{O}_{1.875}$ has been almost perfectly crystallized beyond this temperature.

\subsection{X-ray analysis}

Figure 2a shows the XRD patterns of the synthesized $\mathrm{Ce}_{0.8} \mathrm{Sm}_{0.2} \mathrm{O}_{1.9}, \quad \mathrm{Ce}_{0.75} \mathrm{Sm}_{0.2} \mathrm{Nd}_{0.05} \mathrm{O}_{1.875}$, $\mathrm{Ce}_{0.65} \mathrm{Sm}_{0.2} \mathrm{Nd}_{0.15} \mathrm{O}_{1.825}, \mathrm{Ce}_{0.6} \mathrm{Sm}_{0.2} \mathrm{Nd}_{0.2} \mathrm{O}_{1.8}$ powders after calcination at $600{ }^{\circ} \mathrm{C}$ for $3 \mathrm{~h}$. It can be clearly seen that all powders were single-phased with a cubic fluorite structure (JCPDS powder diffraction file no. 34-0394).

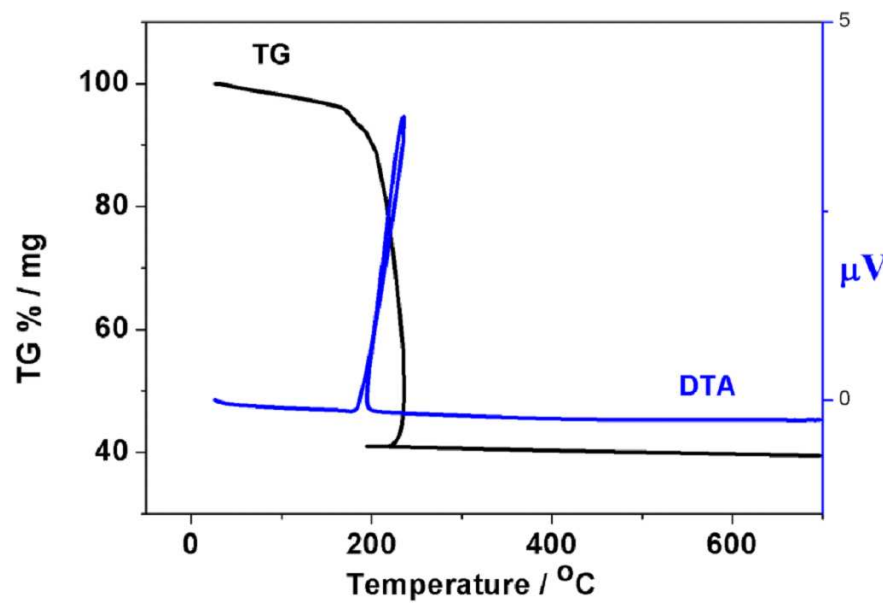

Fig. 1. TG-DTA curves of thermal decomposition of $\mathrm{Ce}_{0.75} \mathrm{Sm}_{0.20} \mathrm{Nd}_{0.05} \mathrm{O}_{1.875}$ powder precursors at a heating rate of $5^{\circ} \mathrm{C} \mathrm{min}^{-1}$ in static air.

No other peaks attributed to impurities or other phases, $\mathrm{Sm}_{2} \mathrm{O}_{3}$ or $\mathrm{Nd}_{2} \mathrm{O}_{3}$, were detected. Thus, single fluoritephased $\quad \mathrm{Ce}_{0.8} \mathrm{Sm}_{0.2} \mathrm{O}_{1.9}, \quad \mathrm{Ce}_{0.75} \mathrm{Sm}_{0.2} \mathrm{Nd}_{0.05} \mathrm{O}_{1.875}$, $\mathrm{Ce}_{0.65} \mathrm{Sm}_{0.2} \mathrm{Nd}_{0.15} \mathrm{O}_{1.825}, \quad \mathrm{Ce}_{0.6} \mathrm{Sm}_{0.2} \mathrm{Nd}_{0.2} \mathrm{O}_{1.8}$ powders can be synthesized successfully using the Pechini method.

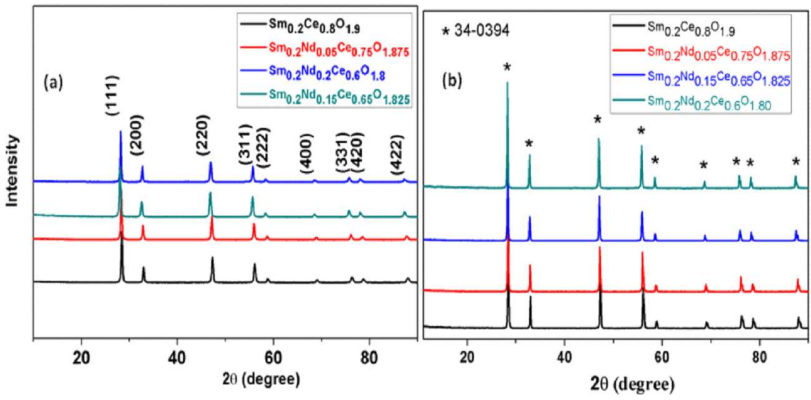

Fig. 2. X-ray diffraction patterns of the synthesized $\quad \mathrm{Ce}_{0.8} \mathrm{Sm}_{0.2} \mathrm{O}_{1.9}, \quad \mathrm{Ce}_{0.75} \mathrm{Sm}_{0.2} \mathrm{Nd}_{0.05} \mathrm{O}_{1.875}$, $\mathrm{Ce}_{0.65} \mathrm{Sm}_{0.2} \mathrm{Nd}_{0.15} \mathrm{O}_{1.825}, \mathrm{Ce}_{0.6} \mathrm{Sm}_{0.2} \mathrm{Nd}_{0.2} \mathrm{O}_{1.8}$ powders after (a) calcination at $600^{\circ} \mathrm{C}$ for $3 \mathrm{~h}$, (b) sintering at $1400^{\circ} \mathrm{C}$ for $6 \mathrm{~h}$.

It can also be seen from XRD patterns that during powder combustion, $\mathrm{Sm}^{3+}$ and $\mathrm{Nd}^{3+}$ co-doped ceria electrolytes are formed by substituting $\mathrm{Ce}^{4+}$ with doping elements $\mathrm{Sm}^{3+}$ and $\mathrm{Nd}^{3+}$; therefore, a complete solid solution may be formed. The broad peaks shown in Fig. 2a indicate the existence of nanosized crystallites formed during the calcination process. From the X-ray diffractograms, the crystallite size, $D$, is calculated from wellknown Scherrer's formula

$$
D=K \lambda /(\beta \cos \theta),
$$

where $D$ is the crystallite size $(\mathrm{nm}), K$ is the constant taken as $0.9, \lambda$ is wavelength of radiation $(0.154056 \mathrm{~nm}$ for $\mathrm{Cu} K_{\alpha}$ ), $\beta$ is the corrected peak at full width at half maximum (FWHM) intensity and $\theta$ is the scattering angle of the main reflection (111). The av- 
erage crystallite size $(D)$ of all crystallite powders was between 54 and $62 \mathrm{~nm}$. The co-doping of rare-earth oxides into $\mathrm{CeO}_{2}$ can cause a small shift in the ceria peaks. Figure $2 \mathrm{~b}$ displays the XRD patterns of $\mathrm{Ce}_{0.8} \mathrm{Sm}_{0.2} \mathrm{O}_{1.9}, \mathrm{Ce}_{0.75} \mathrm{Sm}_{0.2} \mathrm{Nd}_{0.05} \mathrm{O}_{1.875}$, $\mathrm{Ce}_{0.65} \mathrm{Sm}_{0.2} \mathrm{Nd}_{0.15} \mathrm{O}_{1.825}, \mathrm{Ce}_{0.6} \mathrm{Sm}_{0.2} \mathrm{Nd}_{0.2} \mathrm{O}_{1.8}$ pellets after sintering of powders at $1400^{\circ} \mathrm{C}$ for $6 \mathrm{~h}$. It can be observed that the peaks shift to lower $2 \theta$ values on increasing the amount of the $\mathrm{Nd}$ dopant. The ionic radii of $\mathrm{Sm}^{3+}, \mathrm{Nd}^{3+}$, and $\mathrm{Ce}^{4+}$ decrease in the order $r_{N d^{3+}}$ $>r_{\mathrm{Sm}^{3+}}>r_{\mathrm{Ce}^{4+}}$; thus, with more substitution of $\mathrm{Ce}^{4+}$ with increasing $\mathrm{Nd}^{3+}$, the volume of the $\mathrm{CeO}_{2}$ unit cell will be further enlarged and may result in a peak shifting towards lower $2 \theta$ values.

\subsection{FTIR analysis}

Figure 3 displays FTIR spectral features of Sm and Nd co-doped ceria samples. The broad band of weak intensity occurring in the range $3500-3400 \mathrm{~cm}^{-1}$ is due to the $\mathrm{O}-\mathrm{H}$ stretching vibration of the $\mathrm{OH}$ groups. The weak bands at $\approx 1070 \mathrm{~cm}^{-1}$ correspond to the $\nu(\mathrm{O}-\mathrm{H})$ mode of (H-bonded) water molecules and $\delta(\mathrm{OH})$, respectively.

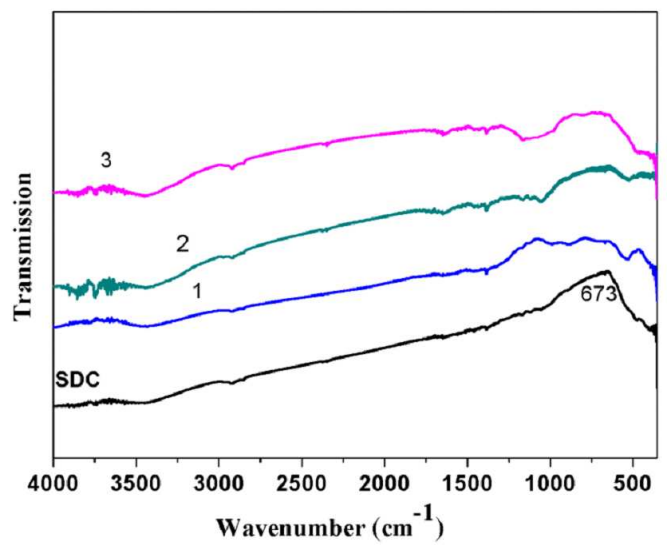

Fig. 3. FTIR spectra of the calcined SDC, 1: $\mathrm{Ce}_{0.75} \mathrm{Sm}_{0.2} \mathrm{Nd}_{0.05} \mathrm{O}_{1.875}, 2: \mathrm{Ce}_{0.65} \mathrm{Sm}_{0.2} \mathrm{Nd}_{0.15} \mathrm{O}_{1.825}$ and 3: $\mathrm{Ce}_{0.6} \mathrm{Sm}_{0.2} \mathrm{Nd}_{0.2} \mathrm{O}_{1.8}$ powders at $600{ }^{\circ} \mathrm{C}$ for $3 \mathrm{~h}$.

$\mathrm{KBr}$ pellets containing sample were used in FTIR measurements. The water peak at $\approx 3400$ and 1070 is due to the moisture in $\mathrm{KBr}$. (The finely powdered potassium bromide absorbs more humidity (it is hygroscopic) from air during sample preparation.) The FTIR spectrum of the $\mathrm{Sm}$ and Nd co-doped ceria also exhibits strong broad band at $700-360 \mathrm{~cm}^{-1}$ which are attributed to the characteristic $\mathrm{Ce}-\mathrm{O}$ vibrations $[13,14]$.

\subsection{Microstructure}

The micro-structures of the SDC pellets sintered at $1400^{\circ} \mathrm{C}$ for $6 \mathrm{~h}$ with different neodymium doping are compared in Fig. 4.

As seen from SEM images (Fig. 4), all samples are nearly fully dense with very few residual pores. There
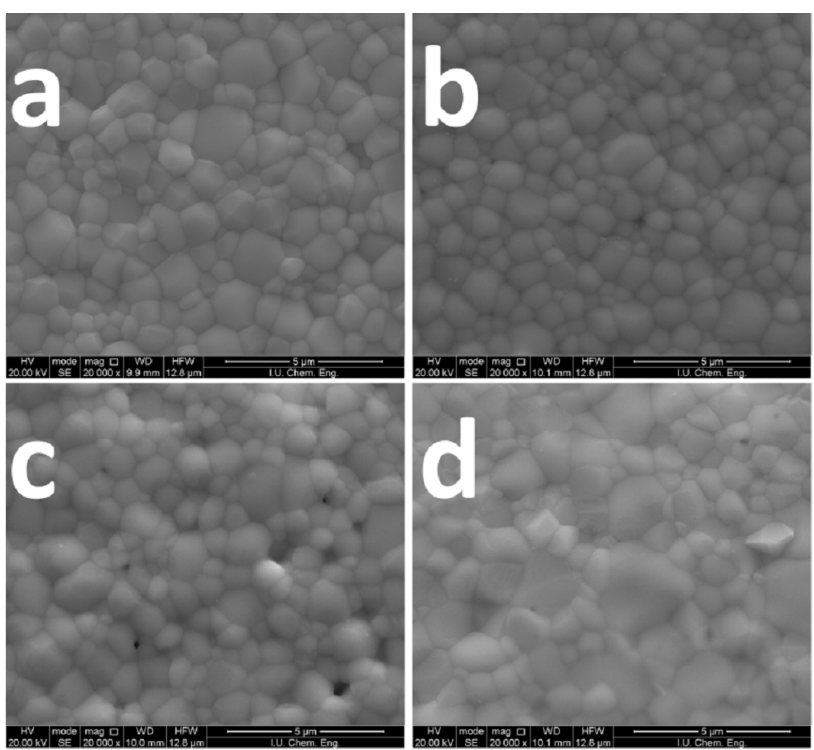

Fig. 4. Scanning electron micrographs of sintered (a) $\mathrm{Ce}_{0.8} \mathrm{Sm}_{0.2} \mathrm{O}_{1.9}, \quad$ (b) $\mathrm{Ce}_{0.75} \mathrm{Sm}_{0.2} \mathrm{Nd}_{0.05} \mathrm{O}_{1.875}$ (c) $\mathrm{Ce}_{0.65} \mathrm{Sm}_{0.2} \mathrm{Nd}_{0.15} \mathrm{O}_{1.825}$, (d) $\mathrm{Ce}_{0.6} \mathrm{Sm}_{0.2} \mathrm{Nd}_{0.2} \mathrm{O}_{1.80}$ $(20.000 \times)$

is no exaggerated grain growth and the average particle size observed from micrographs is approximately $1 \mu \mathrm{m}$ for $\mathrm{Ce}_{0.8} \mathrm{Sm}_{0.2} \mathrm{O}_{1.9}, \quad \mathrm{Ce}_{0.75} \mathrm{Sm}_{0.2} \mathrm{Nd}_{0.05} \mathrm{O}_{1.875}$, $\mathrm{Ce}_{0.65} \mathrm{Sm}_{0.2} \mathrm{Nd}_{0.15} \mathrm{O}_{1.825}$. However, the average particle size increased to $1.16 \mu \mathrm{m}$ for the sample $\mathrm{Ce}_{0.6} \mathrm{Sm}_{0.2} \mathrm{Nd}_{0.2} \mathrm{O}_{1.8}$. No significant effect of $\mathrm{Nd}$ addition on the microstructure of the samarium doped ceria was observed. SEM-EDS map analyses were performed on the outer surface of $\mathrm{Ce}_{0.60} \mathrm{Sm}_{0.20} \mathrm{Nd}_{0.20} \mathrm{O}_{1.80}$ sample which is given in Fig. 5. As can be seen, Ce, Sm, and $\mathrm{Nd}$ are homogeneously dispersed in the structure. The calculated relative densities for $\mathrm{Ce}_{0.8} \mathrm{Sm}_{0.2} \mathrm{O}_{1.9}$, $\mathrm{Ce}_{0.75} \mathrm{Sm}_{0.2} \mathrm{Nd}_{0.05} \mathrm{O}_{1.875} \mathrm{Ce}_{0.65} \mathrm{Sm}_{0.2} \mathrm{Nd}_{0.15} \mathrm{O}_{1.825}$ are approximately $90 \%$ of the theoretical value. On the other hand, $\mathrm{Ce}_{0.6} \mathrm{Sm}_{0.2} \mathrm{Nd}_{0.2} \mathrm{O}_{1.80}$ sample had the highest density of $95 \%$ which suggests that it was the compact one.
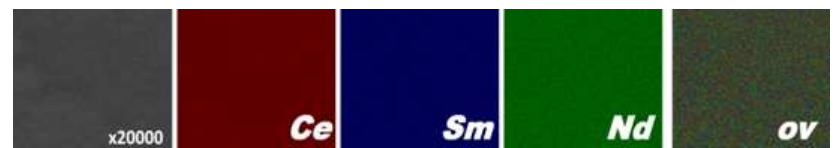

Fig. 5. SEM-EDS map

$\mathrm{Ce}_{0.6} \mathrm{Sm}_{0.2} \mathrm{Nd}_{0.2} \mathrm{O}_{1.80}$ sample.

\subsection{Conductivity measurement}

The ionic conductivity measurement was performed in air at $800^{\circ} \mathrm{C}$. A complex plane plot of real impedance, $Z^{\prime}$, versus imaginary impedance, $Z^{\prime \prime}$, was prepared for each set of data. By curve fitting a circle to semicircles on these plots, sample resistances $\left(R_{\text {total }}=R_{\mathrm{gi}}+R_{\mathrm{gb}}\right)$ were obtained [15]. The total conductivity $\left(\sigma_{\mathrm{T}}\right)$ values were then calculated using the equation 


$$
\sigma_{\mathrm{T}}=\frac{l}{A R_{\mathrm{total}}},
$$

where $l$ is the thickness, $A$ is the cross-sectional area of the sample. Figure 6 shows the complex impedance spectra plots of $\mathrm{Ce}_{0.8} \mathrm{Sm}_{0.2} \mathrm{O}_{1.9}$ and $\mathrm{Ce}_{0.6} \mathrm{Sm}_{0.2} \mathrm{Nd}_{0.2} \mathrm{O}_{1.8}$ samples at $800^{\circ} \mathrm{C}$.

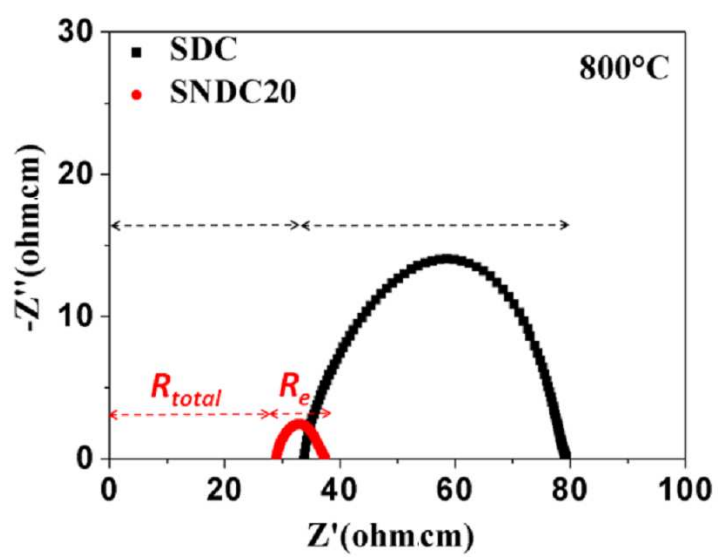

Fig. 6. Complex impedance spectra plots of $\mathrm{Ce}_{0.8} \mathrm{Sm}_{0.2} \mathrm{O}_{1.9} \quad$ (SDC) and $\mathrm{Ce}_{0.6} \mathrm{Sm}_{0.2} \mathrm{Nd}_{0.2} \mathrm{O}_{1.8}$ (SNDC20) pellets sintered at $1400{ }^{\circ} \mathrm{C}$, measured at $800^{\circ} \mathrm{C}$ in air. The total resistance $\left(R_{\text {total }}\right)$ and electode contributions are represented as $R_{\text {total }}, R_{e}$, respectively.

According to the electrochemical impedance spectroscopy results, $\mathrm{Ce}_{0.6} \mathrm{Sm}_{0.2} \mathrm{Nd}_{0.2} \mathrm{O}_{1.80}$ exhibited a total conductivity of $3.50 \times 10^{-2} \mathrm{~S} \mathrm{~cm}^{-1}$ and $\mathrm{Ce}_{0.8} \mathrm{Sm}_{0.2} \mathrm{O}_{1.9}$ showed a total conductivity of $2.95 \times 10^{-2} \mathrm{~S} \mathrm{~cm}^{-1}$ at $800{ }^{\circ} \mathrm{C}$. Neodymium co-dopants improved the electrical conductivity of Sm-doped ceria by $\approx 20 \%$.

\section{Conclusions}

$\mathrm{Ce}_{0.8} \mathrm{Sm}_{0.2} \mathrm{O}_{1.9}, \quad \mathrm{Ce}_{0.75} \mathrm{Sm}_{0.2} \mathrm{Nd}_{0.05} \mathrm{O}_{1.875}$, $\mathrm{Ce}_{0.65} \mathrm{Sm}_{0.2} \mathrm{Nd}_{0.15} \mathrm{O}_{1.825}, \mathrm{Ce}_{0.6} \mathrm{Sm}_{0.2} \mathrm{Nd}_{0.2} \mathrm{O}_{1.8}$ powders were successfully synthesized by the Pechini method, using their corresponding metal nitrates as oxidizers and citric acid as a combustion fuel. All the electrolyte samples were found to be fluorite-type ceria based solid solutions, which were formed in the calcination process at $600{ }^{\circ} \mathrm{C}$ and crystallized better in the sintering process at $1400^{\circ} \mathrm{C} . \quad \mathrm{Ce}_{0.6} \mathrm{Sm}_{0.2} \mathrm{Nd}_{0.2} \mathrm{O}_{1.80}$ sample had good sinterability at $1400^{\circ} \mathrm{C}$, giving relative high density of $95 \%$ and grain size of about $1.16 \mu \mathrm{m}$. According to SEM results, no significant effect of $\mathrm{Nd}$ addition on the micro-structure of the samarium doped ceria was observed. Co-dopants improved the electrical conductivity of Sm-doped ceria, and thus, there is a significant potential for the use of $\mathrm{Ce}_{0.6} \mathrm{Sm}_{0.2} \mathrm{Nd}_{0.2} \mathrm{O}_{1.8}$ electrolyte material for the intermediate temperature SOFCs.

\section{Acknowledgments}

The authors gratefully acknowledge the financial support of the TUBITAK (Project number: 114M238).

\section{References}

[1] H. Inaba, H. Tagawa, Solid State Ionics 83, 1 (1996).

[2] J.A. Kilner, Solid State Ionics 129, 13 (2000).

[3] X. Guan, H. Zhou, Y. Wang, J. Zhang, J. Alloys Comp. 464, 310 (2008).

[4] G. Kim, N. Lee, K. Beum Kim, B.K. Kim, H. Chang, S.J. Song, J.Y. Park, Int. J. Hydrogen. Energy 38, 157 (2013).

[5] V. Prashanth Kumar, Y.S. Reddy, P. Kistaiah, G. Prasad, C. Vishnuvardhan Reddy, Mater. Chem. Phys. 112, 711 (2008).

[6] B. Choudhury, A. Choudhury, Curr. Appl. Phys. 13, 217 (2013).

[7] F.Y. Wang, S. Chen, S. Cheng, Electrochem. Commun. 6, 743 (2004).

[8] R. Torrens, N.M. Sammes, G. Tompsett, J. Electroceram. 13, 683 (2004).

[9] C. Ramesh, C.V. Reddy, Acta Phys. Pol. A 115, 909 (2009).

[10] S. Dikmen, H. Aslanbay, E. Dikmen, O. Sahin, J. Power Sources 195, 2488 (2010).

[11] B. Li, Y. Liu, X. Wei, W. Pan, J. Power Sources 195, 969 (2010).

[12] H.C. Yao, Y.X. Zhang, J.J. Liu, Y.L. Li, J.S. Wang, Z.J. Li, Mater. Res. Bull. 46, 75 (2011).

[13] K.C. Anjaneya, G.P. Nayaka, J. Manjanna, G. Govindaraj, K.N. Ganesha, Solid State Sci. 26, 89 (2013).

[14] Y. Tao, J. Shao, J. Wang, W. Wang, J. Alloys Comp. 484, 729 (2009).

[15] A. Arabacı, V. Sarıboğa, M.F. Öksüzömer, Metall. Mater. Trans. A 45, 5259 (2014). 